\title{
Metaphors of Animal Names in Indonesian
}

\author{
I Dewa Putu Wijana \\ Faculty of Cultural Sciences, Gadjah Mada University \\ idp_wijana@yahoo.com
}

This article concerns with the use of metaphors for constructing animal names in Indonesian. By using data collected from Indonesian Standard Dictionary and cognitive metaphorical theory, it is found that the animals names can be expressed in various forms and the metaphors are possibly placed on the head, attribute, or the whole of construction. The source domains of the metaphors are taken from entities that exist in the speakers' environment and they are projected to the target domains through similarities and associations. As result of, Indonesian relation to other languages, the influence of foreign languages and local languages in the formation of metaphors cannot be avoided.

Key Words: metaphor, source domain, target domain, similarity, and association.

\section{INTRODUCTION}

Long before the word tapir, pig like animal, entered the Indonesian vocabulary, Indonesian native speakers have already had at least five expressions to name this animal. Those are babi alu, babi gajah, babi murai,kuda arau and badak babi. These names clearly show that Indonesian native speakers have three kinds perception about this animal. One time they perceive it as babi 'pig' and the other occasions they perceive it askuda 'horse, and badak 'rhinoceros'. And, in order to specify this animal from the common pig and rhinoceros they used to see, Indonesian speakers also exploit some words that refer to animal names or another to modify the noun which function as the head of the phrase or compound. Those modifiers are alu 'rice pestle', gajah 'elephant', murai 'Copshychussaularis', and babi 'pig'. These phenomena indicate that before the native speakers recognized scientific nomenclatures, they had already practiced traditional ways of naming things or objects which exist surround their living place. The naming practices are carried out by observing the similarities and associations between the object (human beings, plants, animal, actions, etc.) they want to name and everything that already exist in their social and cultural environment. This like wise naming practices will cause the emergence of numerous kinds of metaphor in human languages.

This paper will deal with metaphorical expression of animal names in Indonesian. This topic is important to discuss because it has a number of interesting problems to address which up till now have not so far been seriously handled by the linguists. For instance, despite the expression forms used to convey the animal metaphors are various(word and idiom or phrase), the semantic problems concealed by such expressions are very complicated as well. The metaphorical expressions can totally refer to different kinds of animal, such as anjingtanah 'mole cricket' which biologically does not belong to any kind of anjing 'dog' but to insect whose behavior showssome similarity to a dog. Babi tanah which literally means 'earth pig' does not refer to any kind of 'pig', but to small animal eating ant or anteater. The expressions can also relatively refer to nearly identical species of animals, such as angsa laut which literally means 'sea swan' is metaphorically used to refer to pelican. Like wise anjing air, anjing laut, and badak gajah which respectively hasliteral meaning 'water dog', 'sea dog', 'elephant rhinoceros' are used to refer to otter, see lion, and hippopotamus. The source domains used by the Indonesian speakers as the similarity or association bases are also various. They can be animals (angsa 'swan', anjing 
'dog', rusa 'deer', etc.) , plants (akar 'root', kunyit 'turmeric', daun 'leaf', etc.) human being (dara'virgin', napoleon 'personal name'), supra natural creatures (raksasa 'giant', hantu 'ghost', etc.). Finally, the similarities or associations used as the grounds between the expression (source domain) and its intention (target domain) are also difficult to describe. Those grounds can be based on shape, habitat, color, behavior, origin, etc. For short, this paper will try to analyze and explain several crucial problems which concern about the form, reference, source domain, and similarity bases of the source domain and the target domain of metaphorical expressions of animal names in Indonesian.

\section{THEORETICAL FRAMEWORK}

Human being is surrounded by unlimited objects which have to be named in order to differentiate one with another. However, they do not have enough linguistic expressions (word, phrase, clause, etc.) to do so. Therefore, they are not able to use different expression to name every object they found in their life. If every object is named by different linguistic expressions, the number of vocabulary in a language would be very large and this kind of language is considered ineffective. The large number of lexical items available in the language are impossible to memorize by the speakers. For this matters Ulmann(1970, 168) states:

"If it were not possible to attach several senses to one word, this would mean a crushing burden on our memory. We would have to pass separate terms of every conceivable subject we might wish to talk about. Polysemy is an invaluable factor of economy and flexibility in language."

To solve this problem, people use the readily provided vocabularies to name the relatively newer objects (animals, plants, buildings, etc.) based on the similarities and associations of what is being talked (target domain) and what it is used to compare (source domain). Consequently, there are a number of metaphors and metonymies emerge in the language. Both metaphor and metonymy are part of polysemy. For sake of conceptualease, in this paper metonymy is treated as a part of metaphor.Even though the two concepts are actually different, in that one is based on similarity (metaphor) and the other is based on association (metonymy), in many cases however such concepts is difficult to identify.

The large number of metaphorical expressions of animal name might not merely causes the various linguistic forms used to convey such animal names, but the locus of metaphorical expressioned source domains used to resemble or associate their similarities to the target domains as well. Because of the close relation between language and culture as suggested by many experts, Revealing how the language speakers compare the target domains and their source domains, will to some extend give help anyone to understand the cultural thought patterns of the speech community which is certainly different from one to another. The various names used by the Indonesian speakers to name tapir, mole cricket,otter, etc. as has been exemplified above, are undeniable facts that a language are inseparable from culture.

\section{Previous Studies}

Metaphors whichexist in large number in any language have been an interesting object to study. In Indonesian this issue has been studied by many scholars, such as Wahab (1980) who studies metaphors and their function to trace ecological system; Nuryatiningsih (2004) studies 
Indonesian metaphors that relate with human body parts; Wijana (2015) and Wijana (2016 a) respectively studies Indonesian metaphors expressed by color terms and its exploitation for creating slangy expressions. By using cognitive approach, Pasaribu (2013) and Prayogi (2013) try to discuss how metaphorical expressions in Indonesia are used to express love and time. The study of metaphors which is the closest to this study is the research done by Wijana (2016 b) that concerns with the use of metaphors in Indonesian plant names. And, this study will be about the use of metaphors for naming animals in Indonesia.

\section{Method}

All data presented in this paper are taken from Indonesian Standard Dictionary (Tim Redaksi Kamus Besar Bahasa Indonesia, 2014). The data are further classified according to the forms and locus of metaphorical expression, source domains, similarities and associations of source domains and the target domains, and socio cultural factors which underlies the metaphorical animal naming.

\section{Research Findings}

The following descriptions are the research findings relate with forms, parts of linguistic expression that convey metaphors, source domains, the similarity and association of the source domains and their target domains, and socio cultural factors that influence their existence.

1. Forms of Indonesian metaphorical animal names

As far as the forms are concerned, Indonesian metaphorical animal names can be expressed in three different linguistic forms. Those are reduplication, poly morphemic word with -an, and phrase. The animal names such as alu-alu 'long snouted fish' and jolong-jolong constitute words resulted from reduplication process in which the morphological process itself functions to express the meaning of 'similarity or likeness'. Alu means 'rice pestle' because ofits similarity with the snout or muzzle of the fish. Jolong-jolong is the other name of this fish in which jolong means 'protrude'. The other forms of Indonesian metaphorical animal names is polymorphemic word with suffix -an to express shape similarity, i.e. kambingan which refer to 'large sea fish with attractive color (Heniocusmonoceros). The most common form used by the Indonesian speakers is post modifier attributive phrase, such as angsalaut 'pelican', ayam mutiara 'guinea fowl', ayam pungguk 'tailless chicken', etc. Angsa which literally means 'swan' is the metaphorical expression bases on the shape or size of the pelican bird. Meanwhile, ayam mutiara gets its name bases on the motive or characteristics of the chicken feather, as well as ayam pungguk for the animal has no tail like an owl. All phrases of Indonesian animal name are post modifier, only one example in the data collection is pre modifier maintaining the old Javanese construction, i.e. gajah mina which refers to 'whale'.

2. Parts of Linguistic Expression convey metaphors

The metaphorical expression of animal names in Indonesian can be placed on the whole of the linguistic expressions, such as ones found in reduplication names alu-alu and jolong-jolong both refer to the same animal, i.e. 'long snouted fish'. Several phrasesof animal names can also entirely express metaphors, such as babi alu 'tapir', babi gajah 'tapir', babi murai 'tapir', etc. because the animal resemble to babi 'pig' and part of the body, the body size, and the skin color are similar to alu 'rice pestle', gajah 'elephant', and murai 'small bird'. In animal 
names expressed by phrases, the metaphorical expressions might also be possible to be placed either on the head, such as anjing tanah 'mole cricket', anjing laut 'see lion', babi tanah 'small animal eating ant', etc. or on the attributes of the phrase such as babi dara 'young female pig', baung kunyit 'yellow skinned river fish', belalang jarum 'needle shaped grasshopper'. Dara 'young female', kunyit 'turmeric', and jarum are metaphorical because of the resemblance of the characteristics, color, and shape of the animals.

In anjing tanah 'mole cricket' and babi tanah, the headsof the phrase anjing and babi refer to totally different animals. Anjing which literally means 'dog' and babi 'pig' are respectively used to refer to insect 'mole cricket' and 'small animal eating ant' because of certain similarity found in both animals. The other examples are kuda laut 'sea horse' in which kuda that literally means 'horse' is used to refer to a kind of fish because of the shape similarity.

3. Source Domains of Indonesian Metaphorical Animal Names

Even though Wahab (1990. 147-148) by using Hale's theoretical frame work has found several source domains for explaining Indonesian metaphors, such as human, animate, live, object, terrestrial, substance, energy, cosmos, and being (See also Wijana, 1995, 178), some of these categories are somehow so generic that for certain purposes, we need to specify them. After having observed the data more carefully, the source domains used by Indonesian speakers to construct the metaphorical animal names from the most common to the least are as follow:

a. Animal

Various kinds of land animal, are exploited by Indonesian speakers to metaphorically name many kinds of land or sea animals found in their surroundingbefore foreign and scientific names enter their language vocabulary. Those animals are, anjing 'dog', babi 'pig', badak 'rhinoceros', kuda 'horse', etc. For instance anjing laut, anjing tanah, and anjing air are respectively used to refer to 'sea lion', 'mole cricket', and 'otter'; babialu, babigajah, and babimurai all refer to the same kind of animal, i.e. 'tapir', while babiwrase refers to 'small fish'. Badak which literally means 'rhinoceros' is used metaphorically to refer to several kinds of similar animal, such as badak babi 'tapir', badak api 'wild and vicious pig', badak air 'Hippopotamus amphibius'. Animal names used metaphorically do not always function as the head of phrase. In ayam pungguk 'tailless chicken', babi gajah 'tapir', and buaya katak 'small crocodile', the metaphorical expressions pungguk, gajah, and katak function as the attributes of the phrase construction.

b. Human, Supra Natural Creature, and God

In the data collection, all lexemes referring to human being, such as raja 'king', dara 'young female ', napoleon 'French personal name' and supra natural creatures such as raksasa 'giant', goliath 'personal name', and dewata 'god' are metaphorically used as attribute of the phrase construction for specifying the meaning of the head. For instance burung dara,Ikan napoleon, gurita raksasa, kumbang goliath, and burung dewata are consecutively used to refer to 'pigeon', 'Tilapianilotica', 'octopus giganteus', 'the strongest beetle', and 'bird of paradise'. 
c. Tool and musical instrument

Traditional tools and musical instrument used for expressing metaphorical animal names are alu'rice pestle, sendok 'spoon, gantang 'rice measurement', jarum 'needle', martil 'hammer', serunai 'wood clarinet', etc. Alu-alu, ular sendok, baung gantang, belalang jarum, hiu kepala martil, and biawak serunai respectively refer to 'long snouted fish', 'cobra', 'Short round shaped river fish', 'needle shaped grasshopper', 'SphyrnaZygaena', and 'long pointed mouthed lizard'. In the data collection, there are many more tools or utensils used for expressing metaphors to name various kind of animals.

d. Plant and Its part

Several domestic plants and their parts are used to be source domains of metaphors for naming animals in Indonesian. Kunyit 'turmeric', akar 'root', cabai 'chilly', pandan 'pandanus', kacang '(long) bean', etc. are some of the plants and and their parts found in Indonesian to attribute phrases of animal name. For examples baung akar 'long round shaped river fish', baung kunyit 'yellow skinned river fish', belalang kunyit 'yellow colored locust', burung cabai 'red headed bird', and buaya pandan 'green skinned crocodile'.

e. Mines and Jewels

Mas 'gold', tembaga 'cooper', nilam 'sapphire', permata 'jewel', and mutiara 'pearl' are some of the minerals and jewels used for expressing metaphorical parts of animal phrase names in Indonesian. Ikan mas, buaya tembaga, burung nilam, and ayam mutiara respectively refer to 'gold fish', 'yellowish crocodile', and 'golden oriole', and 'guinea fowl'.

f. Places

It cannot be denied that most places to name animal Indonesian still maintain their literal meanings, such as ayam kedu 'Keduchiken', kucing persia 'persian cat', itik bali 'Balinese duck', itik alabio 'duck bred in Alabio (south Borneo) etc. However, some places such as Bangkok, Belanda, etc. have lost their literal sense because they are associatively used for referring other things. Bangkok is associated with 'big' and Belanda with 'something strange and different' from the animal of such kind. For example kucing belanda and ayam bangkok refer to 'rabit' and 'big sized chicken'. Sometime the place is not a natural one, such as burungsurga 'bird of paradise' for describing the physical beauty of the species.

g. Sky Object and Energy

Bulan 'moon' and komet 'comet' are sky objects found to be used as source domains of animal name in Indonesian. Ikan bulan and ikan komet refer to 'long round fish found in Atlantic' and 'long tailed fish'. Meanwhile, api 'fire' is used to attribute badak 'rhinoceros' for constructing badakapi 'wild and vicious pig' because of the similar characteristics of the creature.

4. Similarities and Associations between the Source Domain and target domain

Theoretically metaphorical expressions can only exist because of certain similarities or associations between the target domain (what are talked about) and the source domains (what are used as comparison) (See Riemer, 2010, 246). In more older fashioned theories, the target domain is equal to tenor, source domains is the same as vehicle, and the similarity and association between them are called ground. Having observed more closely the data 
collection, the similarities and associations found in Indonesian animal names include: shape and size, body color and feather or fur motive, physical strength and living behavior, physical beauty, and state

a. Shapeand Size

Shapes of the animal or part of its body is the most common entity which grounds the source domain and the target domain of metaphorical animal names in Indonesian. For example angsa laut, burung hantu, anjing laut, badak babi, burung onta, etc. respectivelyget their names because of shape similarity between swan and pelican, ghost and owl, rhinoceros, pig, and the tapir, camel and ostrich. The shape similarity may also merely involve part of the animal body, such as ikan komet 'long tailed fish', babi rusa 'deer hogs', babi alu, biawak serunai, etc. These animals get such names because of the similarity between the tail of the fish and the tail of the star which is really a mass o ice and dust (Horby, 2010, 285), the animal tusk and the deer horn, the rice pestle and the snout of the animal, and the lizard snout and the wood clarinet.

As far as the Indonesian animal names are concerned, the size involved in the naming practices can be differentiated into three concepts, i.e. big, small, and long. The first concept is represented by gajah 'elephant', raksasa 'giant', badak 'rhinoceros', and raja 'king', such as gajah mina 'whale', badak gajah 'big rhinoceros', gurita raksasa 'octopus giganteus', burung badak 'horn bill', and kepiting raja 'big crab found in Pacific', while the second one is expressed by kacang 'bean', katak 'frog', and kambing 'goat', such as kambing kacang 'goat with smaller body than ordinary goat', buaya katak 'small crocodile', and kijang kambing 'light yellow small deer'. Finally the word galah 'punting pole' are commonly used for representing the animal length, such as ketam galah 'long legged crab' and udang galah 'big and long shrimp'.

b. Body Color and Feather or Fur motive

Words that are used metaphorically to express the physical characteristics of Indonesian animals are emas 'gold', tembaga 'cooper', kunyit 'turmeric', gading 'tusk', and nilam 'shapir' for representing yellow body color; jalak 'stirling', and murai 'small bird' for representing black, kunyit 'turmeric' for representing red, Belanda for representing albino, and pandan 'pandanus' for representing green. For this matter consider ikan emas 'gold fish', buaya tembaga 'yellowish crocodile', enggang gading 'hinoplax vigil', Burungnilam 'golden oriole', ayamjalak 'speckled chiken, babimurai 'tapir, belalangkunyit 'red locust', kera belanda 'proboscis monkey of Borneo', and buaya pandan 'green skinned crocodile'. It is interesting to note that ikan mangsi 'squid' gets their name because the similar color of of Javanese borrowing mangsi 'ink' and the liquid the animal produces to deceive its predator'. In case of ayam mutiara 'guinea fowl', the similarity is based on the animal feather motive.

c. PhysicalStrength and Living Behavior

Napoleon 'French personal name' and Goliath 'a powerful giant in the Bible who is killed by David with a stone' are two among other well known foreign names famous in Indonesian society. These names are then exploited are to describe metaphorically the living behavior and the physical strength of the Indonesian animals. For examples, ikan 
napoleon and kumbang goliath refer to 'fish which seemingly has the same living behavior as Napoleon Bonaparte' and 'the heaviest beetle with strong front leg found in Africa that belongs to Scarabaeidae family'.

d. Physical Beauty

The beauty of animal physical appearance can be use as the ground of the source domain and the target domain of the metaphor, such as found in burung dewata and burung surge in which dewata and surge respectively means 'god' and 'paradise, heaven'.

e. State and Characteristics

State and characteristics of the animal are some time used as the ground of the similarity or the association, such as babi dara 'young female pig' and badak api 'wild vicious pig' are so called because of the similarity between dara 'young female woman' and the age of the animal, as well as the characteristics of api 'fire' which often burns everything closed by that is similar to the animal's behavior.

SOCIO CULTURAL FACTORS UNDERLYING THE INDONESIAN METAPHORICAL ANIMAL NAMES

Everything has been described above clearly shows that people living environment together with its custom, strongly influence the naming practices, particularly that involves the use of metaphors for calling various kinds of animal living surround them. Nearly all the source domains of the metaphor constitute traditional instruments, utensils, animals, plants, or supra natural creatures to which they have already beenfamiliar with. Because there is no language, no matter remote and nomadic its people might be, without being influenced by other languages , the use of loan words from foreign languages or local languages as well (Foley, 2001, 382), such as Goliath, Napoleon, and mangsi, and sumpit (Ikan sumpit 'toxotesjaculator') cannot be avoided.

\section{CONCLUSION}

Metaphor is one of essential linguistics devices to develop the capacity of a language to avoid the vast increasing number of vocabulary which is potential to burden the memory of the speakers. By metaphors, the new concepts can be expressed by words or words combination base on similarities or analogies. The metaphorical expressions may be placed on the head, attribute, or entirely on the whole of construction phrases. With regards to Indonesian animal names, the source domains can be traditional tools, family utensils, animal, human, supra natural creature sky objects, and any kind of entity exist in the speakers environment. These source domains are cognitively projected to their target domains base on various similarities and analogy, such as shape, size, color, physical strength and beauty, living behavior, etc. 


\section{REFERENCES}

Foley, William A. 2001. Anthropological Linguistics: An Introduction. Oxford: Blackwell. Hornby, A,S. 2010. Oxford Advance Learner's Dictionary. Oxfod University Press.

Nuryatiningsih, Farida. 2004. PerpaduanLeksemAnggotaTubuhdalamBahasa Indonesia. Tesis PascaSarjana Universitas Gadjah Mada.

Pasaribu, Truly Almendo. 2013. "A Cognitive Linguistic Analysis of Indonesian Love Metaphors". Prosiding Seminar Internasional dari Berbagai Perspektif. Program Studi S2 Linguistik. Fakultas Ilmu Budaya Universitas Gadjah Mada.

Prayogi, Icuk. 2013. "Bentuk-bentuk Metafora Temporal Bahasa Indonesia (TinjauanAwal). Prosiding Seminar Internasional Studi Bahasa dari Berbagai Perspektif. Program Studi S2 Linguistik. Fakultas Ilmu Budaya Universitas Gadjah Mada.

Riemer, Nick. 2010. Introducing Semantics. Cambridge University Press.

Tim Redaksi Kamus Besar Bahasa Indonesia. 2014. Kamus Besar Bahasa Indonesia Pusat Bahasa. Edisi ke-4. Jakarta: Gramedia Pustaka Utama.

Ullmann, Stephen. 1970. Semantics: An Introduction to the Science of Meaning. Oxford: Basil Blackwell.

Wahab, Abdul. 1980. "Metafora sebagai Alat Pelacak Sistem Ekologi”. Pertemuan Linguistik Lembaga Bahasa Atma Jaya III. Yogyakarta: Kanisius.

Wijana, I Dewa Putu. 2016 a. "Source Domains of Indonesian Slangy Metaphorical Expressions". The $4^{\text {th }}$ Graduate Student Conference Proceeding. pp. 1-8. Yogyakarta: Sanata Dharma University.

Wijana, I DewaPutu. 2016 b. "The Use of Metaphors in Indonesian Plant Names", Language Literature\& Society. (Harris HermansjahSetiajid (Ed.). Yogyakarta. Departement of Engslish Letters Sanata Dharma University.

Wijana, I DewaPutu. 1995. Wacana Kartun dalam Bahasa Indonesia. Disertasi Universitas Gadjah Mada 